\title{
Effects of Low Dosage Progestin-only Administration upon Plasma Triglycerides and Lipoprotein Metabolism in Postmenopausal Women
}

\author{
Bernard M. Wolfe and Murray W. Huff \\ Department of Medicine, University Hospital and The University of Western Ontario, London, Ontario, Canada N6A 5A5
}

\begin{abstract}
Oral administration to five postmenopausal women of $d l$-norgestrel $(0.075 \mathrm{mg} / \mathrm{d}$ for $7 \mathrm{wk})$ reduced mean fasting plasma levels of triglycerides by $29 \%(P<0.001)$, VLDL triglycerides by $39 \%(P<0.01)$, and VLDL apo B by $26 \%(P<0.05)$, while lowering mean total cholesterol by $7 \%(P<0.06)$. To explain these observations the kinetics of VLDL and LDL apo B turnover were studied by injecting autologous ${ }^{125}$ I-labeled VLDL and ${ }^{131}$ I-labeled LDL under control conditions and again in the fourth week of a 7-wk course of $d l$-norgestrel. VLDL apo B pool size fell by an average of $27 \%(1.2 \mathrm{vs} 1.7 \mathrm{mg} / \mathrm{kg}, P<0.06)$ and production of apo $B$ by $18 \%$ (18 vs $22 \mathrm{mg} / \mathrm{kg}$ per d, $P$ $<0.05$ ) with unchanged fractional catabolic rate. Production of LDL apo B increased $36 \%$ with $d l$-norgestrel ( 12 vs $9.4 \mathrm{mg} / \mathrm{kg}$ per $d, P<0.05)$, but this was compensated by a $36 \%$ increase in fractional catabolic rate of LDL apo B ( 0.33 vs 0.25 pools / d, $P$ $<0.005$ ), thereby maintaining pool size. Lipoprotein (a) fell by an average of $12 \%(16 \mathrm{vs} 18 \mathrm{mg} / \mathrm{dl}, P<0.06)$. dl-Norgestrel reduced VLDL triglycerides (40 vs $64 \mathrm{mg} / \mathrm{dl}, P<0.05$ ), intermediate density lipoprotein cholesterol $(14 \mathrm{vs} 19 \mathrm{mg} / \mathrm{dl}, P$ $<0.02$ ), IDL apo B (5.3 vs $7.2 \mathrm{mg} / \mathrm{dl}, P<0.05$ ), and VLDL cholesterol (3.1 vs $5.1 \mathrm{mg} / \mathrm{dl}, 0.10>P>0.05)$, in parallel with the reductions in VLDL apo $B$ production and pool size. $d l$-Norgestrel significantly lowered the production rate of VLDL apo B, thereby decreasing plasma VLDL and intermediate density lipoprotein concentrations. (J. Clin. Invest. 1993. 92:456-461.) Key words: $d l$-norgestrel $\bullet$ lipids • estrogens • turnover $\bullet$ apolipoprotein
\end{abstract}

\section{Introduction}

The synthetic progestin $d l$-norgestrel is used widely pharmaceutically in combination with estrogen in the formulation of oral contraceptives (1) and has also recently been tested in continuous low dosage together with estradiol-17 $\beta$ in the hormonal replacement of symptomatic estrogen-deficient postmenopausal women (2). Combined low dosages of $d l$-norgestrel and estradiol-17 $\beta$ lower plasma cholesterol and triglycerides in postmenopausal women by increasing fractional catabolism of VLDL and reducing production of LDL (3). However, the specific contribution of $d l$-norgestrel to the ob-

Address correspondence to Dr. Bernard M. Wolfe, Division of Endocrinology and Metabolism, Department of Medicine, University Hospital, 339 Windermere Road, London, Ontario, Canada N6A 5A5.

Received for publication 21 February 1991 and in revised form 11 February 1993.

J. Clin. Invest.

(C) The American Society for Clinical Investigation, Inc. $0021-9738 / 93 / 07 / 0456 / 06 \$ 2.00$

Volume 92, July 1993, 456-461 served lowering of lipids is unknown. Although most reports find that oral contraceptives containing $d l$-norgestrel lower plasma triglycerides $(4,5)$, this has not been universal (6-8). Levonorgestrel, the active isomer of $d l$-norgestrel, lowers plasma total and VLDL triglycerides in intact female rats when given alone (9), but not when combined with estradiol (10). The reduction of VLDL apo B levels with levonorgestrel in intact female rats is attributable to enhanced fractional catabolism of VLDL (11). However, inhibition of hepatic triglyceride synthesis could also contribute to reduction of plasma triglycerides because levonorgestrel inhibits incorporation of labeled glycerol and fatty acids into rat hepatocyte triglycerides and reduces their incorporation into triglycerides released into the incubation medium (9). This appears to involve, at least in part, inhibition of the hepatic glycerol-3-phosphate acyltransferase (12). Prophylaxis against postmenopausal coronary heart disease, osteoporosis, endometrial cancer, and stroke (13-15) may be enhanced through improving compliance with female hormonal replacement regimens by administration of continuous low dosages of progestins, such as $d l$-norgestrel, along with estrogen and eliminating the main cause of noncompliance with such therapy which is the scheduled vaginal withdrawal bleeding induced by intermittent administration of progestin (2). To investigate the specific, individual effects of $d l$-norgestrel on plasma apo B in women with estrogen deficiency, we have examined the effects in postmenopausal women of continuous low dosage $d l$-norgestrel on $(a)$ the kinetics of apo B metabolism of VLDL and LDL and $(b)$ the concentration of plasma lipoprotein (a) $[\operatorname{Lp}(a)] .{ }^{1} \mathrm{Lp}(\mathrm{a})$ is closely related to apo B (16) and increases during the menopause (17), along with plasma cholesterol (18), thereby contributing to the loss of relative immunity from coronary heart disease enjoyed by premenopausal women compared with men of similar age (19).

\section{Methods}

Subjects. Five participants were recruited from University Hospital out-patient clinics ( Table I). Each had experienced typical menopausal symptoms and was amenorrheic for at least 6 mo. Serum follicle-stimulating hormone exceeded $110 \mathrm{U} /$ liter before entering the study in all subjects. Baseline fasting plasma cholesterol concentrations during Phase I American Heart Association diets before entry into the study equaled or exceeded $200 \mathrm{mg} / \mathrm{dl}$, the cut-point of eligibility for treatment recommended by the National Cholesterol Education Program (20). Subjects received no other medications known to affect lipid metabolism and intake of ethanol was $<30 \mathrm{ml} / \mathrm{d}$ for the month before each turnover study. All subjects had normal fasting concentrations of serum glucose, glutamic oxaloacetic transaminase, thyroxine, creatinine, calcium, albumin, sodium, potassium, chloride, and bicarbonate. Hematological and urine analyses were normal. The experimental pro-

1. Abbreviations used in this paper: FCR, fractional catabolic rate; IDL, intermediate density lipoprotein; $\operatorname{Lp}(a)$, lipoprotein $a$. 


\begin{tabular}{|c|c|c|c|c|c|c|c|c|c|}
\hline \multirow[b]{2}{*}{ Subject } & \multirow[b]{2}{*}{ Age } & \multirow[b]{2}{*}{ Height } & \multirow[b]{2}{*}{ Weight } & \multicolumn{2}{|c|}{ Cholesterol } & \multicolumn{2}{|c|}{ Triglycerides } & \multicolumn{2}{|c|}{$\operatorname{Lp}(a)$} \\
\hline & & & & Control & Treated & Control & Treated & Control & Treated \\
\hline & $y r$ & $\mathrm{~cm}$ & $\mathrm{~kg}$ & \multicolumn{6}{|c|}{$m g / d l$} \\
\hline 1 & 50 & 163 & 62 & 219 & 213 & 142 & 98 & 14 & 13 \\
\hline 2 & 64 & 162 & 73 & 283 & 229 & 198 & 155 & 21 & 19 \\
\hline 3 & 58 & 160 & 74 & 192 & 182 & 138 & 92 & 28 & 22 \\
\hline 4 & 76 & 152 & 62 & 232 & 224 & 140 & 99 & 9.3 & 7.8 \\
\hline 5 & 68 & 151 & 52 & 279 & 270 & 117 & 88 & 20 & 19 \\
\hline Mean & 63 & 158 & 65 & 241 & $224^{*}$ & 147 & $106^{\ddagger}$ & 18 & $16^{*}$ \\
\hline$\pm \mathrm{SE}$ & 4 & 3 & 4 & 18 & 14 & 14 & 12 & 3 & 3 \\
\hline
\end{tabular}

Values for each subject are the mean of four fasting blood plasma samples obtained over 3 wk during each of the control and treatment periods.

* Different from control, $P<0.06$ by sign test. ${ }^{\ddagger}$ Different from control, $P<0.001$.

tocol approved by The Standing Committee on Human Research of The University of Western Ontario was explained to each subject and informed consent was obtained in writing.

Subjects were maintained on the modified fat diets containing $\sim 30 \%$ of energy from fat $(<300 \mathrm{mg}$ cholesterol per d), $20 \%$ from protein, and $50 \%$ from carbohydrate. The ratio of polyunsaturated:monounsaturated:saturated fat was $\sim 0.7: 1.0: 1.0$. However, during admissions to hospital for the initial day of each turnover study, the subjects consumed low fat diets $(<5 \mathrm{~g}$ fat $/ \mathrm{d}, 62 \mathrm{~g}$ protein/d, and $378 \mathrm{~g}$ carbohydrate/d, consisting of $2 \%$ cottage cheese, cereals, juices, gelatin, and skim milk).

Samples of venous blood for determination of plasma total and HDL cholesterol, total triglycerides and $\mathrm{Lp}$ (a) concentrations were obtained from a forearm vein (after a 12-h fast) from each subject on four occasions at approximately weekly intervals $(a)$ during the initial 3-wk control period before starting $d l$-norgestrel administration and (b) during the treatment period (weeks 3 to 6 of the 7-wk course of $d l$-norgestrel administration, $0.075 \mathrm{mg} / \mathrm{d}$ ). Subjects underwent studies of the kinetics of VLDL and LDL apo B turnover during the control period and again during the last $16 \mathrm{~d}$ of $d l$-norgestrel administration. All subjects received $300 \mathrm{mg}$ potassium iodide daily for $3 \mathrm{~d}$ before and $13 \mathrm{~d}$ after the reinjection of their radiolabeled lipoproteins.

Preparation of labeled lipoproteins and kinetic studies. Fasting blood plasma ( $1.5 \mathrm{mg}$ EDTA $/ \mathrm{ml}$ ) for isolation of VLDL and LDL was obtained from each subject $6 \mathrm{~d}$ before each turnover study. The procedures used for the preparation of the labeled lipoproteins have been previously described $(3,11,21-23)$. VLDL and LDL were radiolabeled with ${ }^{125}$ I (Amersham, Oakville, Canada) and ${ }^{131}$ I (Merck-Frosst Canada Inc., Point Claire-Dorval, Canada), respectively. 96\% of the radioisotope ${ }^{125} \mathrm{I}$ was bound to VLDL protein, $1 \%$ was associated with lipids, and 3\% remained unbound; VLDL apo B accounted for $42 \%$ of the ${ }^{125}$ I bound to VLDL protein. $98 \%$ of the radioisotope ${ }^{131} I$ was bound to LDL protein, $1 \%$ was associated with lipids, and $1 \%$ remained unbound; LDL apo B accounted for $90 \%$ of the ${ }^{131}$ I bound to LDL protein.

Experimental protocol. Each recipient was fasted $12 \mathrm{~h}$ before receiving serially $100 \mu \mathrm{Ci}$ of ${ }^{125}$ I-labeled VLDL and $30 \mu \mathrm{Ci}$ of ${ }^{131}$ I-labeled LDL in 2-3 ml of normal saline over $2 \mathrm{~min}$ via a hand or forearm vein. Venous blood samples (each $25 \mathrm{ml}, 1.5 \mathrm{mg}$ EDTA $/ \mathrm{ml}$ ) were obtained over $16 \mathrm{~d}$ after injection at $0.5,1,2,4,6,8,10,12,24,48,72,120,216$, 288 , and $384 \mathrm{~h}$ and placed on ice before immediate separation of plasma. Plasma VLDL $\left(S_{\mathrm{f}} 60-400\right)$, intermediate density lipoprotein (IDL) $\left(S_{\mathrm{f}} 12-60\right)$, and LDL $\left(S_{\mathrm{f}} 0-12\right)$ were fractionated $(21,24)$ and apo $B$ isolated from each lipoprotein fraction by isopropanol precipitation and its specific activity determined as previously described (25).

Analyses. The structure of the kinetic model and equations used to calculate the kinetic parameters have been described in detail previously (11). The principal assumptions of this model are that $(a)$ apo B is an integral part of each of VLDL, IDL, and LDL, is nonexchangeable and therefore provides an accurate measure of the metabolism of these lipoproteins; $(b)$ the metabolism of the tracer is identical to that of the tracee; $(c)$ the production rate or flux of VLDL apo B is defined as representing input of apo B primarily into the larger, rapidly turning over, primary metabolic compartment (pool 1$) ;(d)$ all apo B catabolism occurs from pool 1 either directly or after passing through either pool 2 or $3 ;(e)$ all subpopulations of VLDL are isolated for labeling and that the initial injected activity is proportional to the mass of apo $B$ in each population; $(f)$ the two-pool model used for LDL apo B analysis is characterized by a plasma compartment and extravascular exchange compartment; and $(g)$ at the time of injection all LDL apo B radioactivity is introduced into the plasma compartment and irreversible loss of LDL apo B occurs from the same compartment.

As in earlier studies in humans and rats, the specific activity curves of VLDL apo B were best described by the three-pool model of Goodman et al. (26), modified according to Skinner (27), that provided a better fit by residual error testing than a two-pool model. The kinetic parameters of this model for VLDL were calculated as previously described $(3,11,26)$. As in a previous study $(3)$, there was no evidence for a third pool for LDL apo B and the specific activity curves of LDL apo $B$ were analyzed and kinetic parameters calculated using the conventional two-pool model of Gurpide et al. $(21,28-30)$. This yielded values for flux rates through pool 1 , irreversible fractional catabolic rate ( $\mathrm{FCR}=k_{\mathrm{A}}$, assuming that catabolism from other pools is negligible) (28), and mass in pool 1 .

The mass of plasma apo B in VLDL and LDL was determined by electroimmunoassay as previously described (31). $\mathrm{Lp}(\mathrm{a})$ was measured using Macra Lp(a) Kit obtained from Terumo Medical Corp., Elkton, MD. The intraassay coefficients of variation for apo B and Lp(a) were 4.5 and $4.7 \%$, respectively. VLDL apo B pool size was determined independently from the plasma concentration of VLDL apo B (31) multiplied by the plasma volume taken as $36 \mathrm{mg} / \mathrm{kg}$ body wt (32). IDL apo B concentration was also determined by electroimmunoassay (31). The FCR was calculated as: $k_{\mathrm{A}}=\alpha \beta /\left(\alpha+\beta-k_{\mathrm{AA}}\right)$ (28). The percentage of LDL apo $B$ that was derived from IDL apo $B$ was calculated as: 1 - (area under the ${ }^{125}$ I-LDL apo B specific activity curve/area under the ${ }^{125}$ I-IDL apo B specific activity curve $) ;(23,33)$. Concentrations of cholesterol and triglycerides in the chloroformmethanol extract of whole plasma were determined as previously described (22), except that diagnostic kits from Boehringer Mannheim GmbH Diagnostica, Montreal, Canada (C-system kit for cholesterol and test combination kit for triglycerides) were used to measure cholesterol content of fasting plasma VLDL, IDL, and LDL and triglyceride content of VLDL during the turnover studies because of the small amounts of material available for assay. HDL cholesterol was measured after precipitation with heparin-manganese chloride (34). Values from control and treatment periods were compared using Student's 
Table II. Effects of dl-Norgestrel on Fasting Levels of Cholesterol of Plasma Lipoproteins during Turnover Studies

\begin{tabular}{|c|c|c|c|c|c|c|c|c|c|c|}
\hline \multirow[b]{2}{*}{ Subject } & \multicolumn{2}{|c|}{ Whole Plasma } & \multicolumn{2}{|c|}{ VLDL } & \multicolumn{2}{|c|}{ IDL } & \multicolumn{2}{|c|}{ LDL } & \multicolumn{2}{|c|}{ HDL } \\
\hline & Control & Treated & Control & Treated & Control & Treated & Control & Treated & Control & Treated \\
\hline & \multicolumn{10}{|c|}{$m g / d l$} \\
\hline 1 & 213 & 205 & 4.9 & 1.2 & 14 & 7.4 & 138 & 142 & 56 & 54 \\
\hline 2 & 284 & 227 & 6.1 & 6.5 & 24 & 16 & 200 & 151 & 54 & 53 \\
\hline 3 & 197 & 183 & 3.9 & 3.7 & 21 & 19 & 123 & 111 & 49 & 49 \\
\hline 4 & 234 & 218 & 7.2 & 2.7 & 15 & 12 & 154 & 145 & 58 & 58 \\
\hline 5 & 288 & 253 & 4.1 & 0.8 & 22 & 16 & 206 & 184 & 56 & 52 \\
\hline Mean & 243 & $217^{*}$ & 5.2 & 3.0 & 19 & $14^{\ddagger}$ & 164 & 147 & 55 & 53 \\
\hline$\pm \mathrm{SE}$ & 18 & 12 & 0.6 & 1.0 & 2 & 2 & 17 & 12 & 2 & 2 \\
\hline
\end{tabular}

Values for each subject were based upon fasting blood plasma samples obtained immediately before injection of autologous labeled ${ }^{125} \mathrm{I}-\mathrm{VLDL}$ and ${ }^{131} \mathrm{I}-\mathrm{LDL}$ at the beginning of each turnover study. ${ }^{*}$ Different from control, $P<0.05$. ${ }^{\ddagger}$ Different from control, $P<0.02$.

paired two-tailed $t$ test (35) or the nonparametric sign test (36) if the difference narrowly failed to achieve $P<0.05$, as specifically noted.

\section{Results}

The oral administration of $d l$-norgestrel $(0.075 \mathrm{mg} / \mathrm{d}$ for 7 wk) significantly lowered mean plasma triglycerides $(P<0.05$, Table I), along with reductions in mean total cholesterol and $\operatorname{Lp}(\mathrm{a})(P<0.06$ by sign test $)$. Based upon measurements on fasting blood plasma obtained during day 1 of the turnover studies, these changes were attributable to corresponding reductions in the concentrations of cholesterol in $(a)$ VLDL, IDL, and LDL (Table II) and $(b)$ VLDL triglycerides ( $40 \pm 10$ vs $64 \pm 9 \mathrm{mg} / \mathrm{dl}, P<0.02)$. Mean values for apo $B$ were signifi- cantly reduced during $d l$-norgestrel treatment versus control in plasma VLDL ( $3.3 \pm 0.4$ vs $4.4 \pm 0.6 \mathrm{mg} / \mathrm{dl}, P<0.01)$ and IDL $(5.3 \pm 0.2$ vs $7.2 \pm 0.7 \mathrm{mg} / \mathrm{dl}, P<0.05)$, whereas LDL apo B was unchanged ( $47 \pm 5$ vs $49 \pm 4 \mathrm{mg} / \mathrm{dl}, P>0.3)$. Consistent with a steady state, there were no systematic changes during the turnover studies in plasma concentrations of the most readily quantified indices, namely total protein content of LDL (mean coefficient of variation of $10 \%$, corresponding to a mean SD of 8 $\mathrm{mg} / \mathrm{dl}, n=6$ paired studies) and VLDL (mean coefficient of variation of $22 \%$, corresponding to a mean SD of $1.1 \mathrm{mg} / \mathrm{dl}, n$ $=6$ paired studies). The ratio of triglycerides to apo $\mathrm{B}$ in plasma VLDL, IDL, and LDL was not significantly altered by $d l$-norgestrel treatment versus control $(8.9 \pm 1.5$ vs $10 \pm 1.8$, $3.9 \pm 0.6$ vs $3.8 \pm 0.6$, and $0.29 \pm 0.05$ vs $0.32 \pm 0.05$, respectively, $P>0.2$ ).

Table III. Kinetic Parameters of Human ${ }^{125}$ I-VLDL Apo B Turnover in dl-Norgestrel-treated Postmenopausal Subjects

\begin{tabular}{|c|c|c|c|c|c|c|c|c|}
\hline \multirow[b]{2}{*}{ Subject } & \multirow[b]{2}{*}{ Period } & \multicolumn{3}{|c|}{ Half-life phase } & \multirow{2}{*}{$\begin{array}{l}\text { Fractional } \\
\text { catabolic } \\
\text { rate }\end{array}$} & \multicolumn{2}{|c|}{$\begin{array}{l}\text { Pool size of } \\
\text { VLDL apo B }\end{array}$} & \multirow{2}{*}{$\begin{array}{l}\text { Production } \\
\text { rate }^{\mathrm{s}}\end{array}$} \\
\hline & & I & II & III & & Kinetic* & Mass ${ }^{\ddagger}$ & \\
\hline & & & $h$ & & pools/d & & & $m g / k g$ per $d$ \\
\hline \multirow[t]{2}{*}{1} & Control & 0.4 & 1.4 & 32 & 15 & 1.6 & 1.3 & 24 \\
\hline & Treated & 0.5 & 1.9 & 35 & 22 & 0.8 & 1.1 & 18 \\
\hline \multirow[t]{2}{*}{2} & Control & 1.0 & 7.5 & 24 & 9.0 & 2.8 & 2.3 & 26 \\
\hline & Treated & 0.4 & 1.0 & 16 & 17 & 1.0 & 1.7 & 18 \\
\hline \multirow[t]{2}{*}{3} & Control & 0.6 & 1.6 & 14 & 15 & 1.3 & 1.5 & 19 \\
\hline & Treated & 0.7 & 2.7 & 17 & 12 & 1.2 & 1.0 & 15 \\
\hline \multirow[t]{2}{*}{4} & Control & 0.5 & 1.4 & 33 & 14 & 1.6 & 1.8 & 22 \\
\hline & Treated & 0.7 & 1.7 & 38 & 15 & 1.5 & 1.2 & 22 \\
\hline \multirow[t]{2}{*}{5} & Control & 0.4 & 1.9 & 26 & 13 & 1.4 & 1.2 & 19 \\
\hline & Treated & 0.5 & 1.6 & 33 & 13 & 1.3 & 0.9 & 17 \\
\hline Mean & Control & 0.6 & 2.8 & 26 & 13 & 1.7 & 1.6 & 22 \\
\hline$\pm \mathrm{SE}$ & & 0.1 & 1.2 & 3 & 1.0 & 0.3 & 0.2 & 1.4 \\
\hline Mean & Treated & 0.6 & 1.8 & 28 & 16 & $1.2^{11}$ & $1.2^{\prime}$ & $18^{* *}$ \\
\hline$\pm \mathrm{SE}$ & & 0.1 & 0.3 & 5 & 1.8 & 0.1 & 0.1 & 1.1 \\
\hline
\end{tabular}

* Based upon kinetic analysis of ${ }^{125}$ I-labeled VLDL apo B (see Methods). ${ }^{\ddagger}$ Mean values based upon plasma mass determined by electroimmunoassay on fasting specimens obtained daily during the first $4 \mathrm{~d}$ of each turnover study (31). Plasma volume was assumed to be $36 \mathrm{ml} / \mathrm{kg}$ (32). ${ }^{8}$ Based upon product of fractional catabolic rate and radioisotopic determination of VLDL apo B pool size. "Different from control, $P<0.06$ by sign test. 'Different from control, $P<0.01$. ** Different from control, $P<0.05$. 


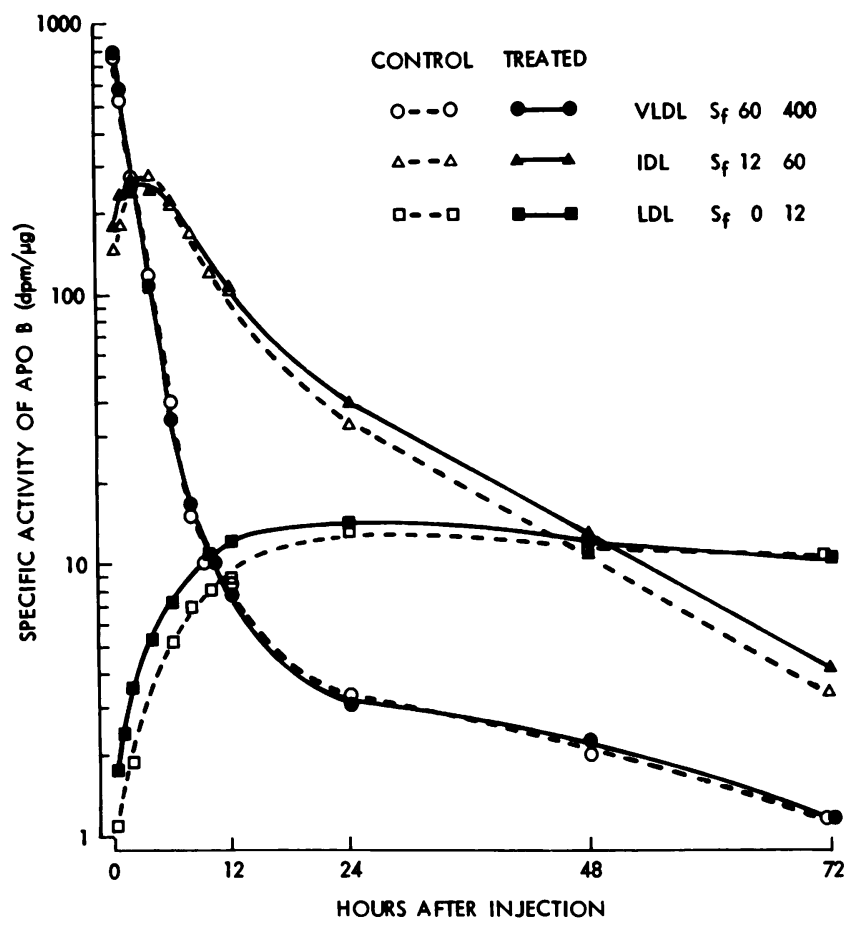

Figure 1. Specific activities of apo B of VLDL, IDL, and LDL after intravenous injection of autologous ${ }^{125}$ I-labeled VLDL during control (open symbols) and treatment (closed symbols) for a representative subject.

Values for the specific activities of ${ }^{125}$ I-labeled apo $B$ in VLDL, IDL, and LDL over $72 \mathrm{~h}$ after injection of ${ }^{125}$ I-labeled VLDL during $d l$-norgestrel treatment versus control are shown in Fig. 1. The kinetic parameters of VLDL turnover calculated from the ${ }^{125}$ I-labeled VLDL apo B decay curves are shown in Table III. During the treatment versus control periods, there were no significant differences in FCR; however, mean VLDL apo B production rate fell significantly by $18 \pm 5 \%$ $(P<0.05)$ and mean VLDL apo B pool size determined by kinetic analysis fell by $27 \pm 12 \%(P<0.06$ by sign test $)$.

Fig. 2 illustrates the effect of $d l$-norgestrel administration on the percent decrease of the ${ }^{131}$ I-labeled LDL apo B specific activity from the plasma for a representative subject. The kinetic parameters of LDL turnover calculated from the ${ }^{131} \mathrm{I}-\mathrm{la}$ beled LDL decay curves using the two-pool model of Gurpide et al. (27) are shown in Table IV. Based on these curves the half-life of phase I, but not phase II, was significantly shorter during the treatment versus control $(39 \pm 4$ vs $21 \pm 2 \mathrm{~h}, P$ $<0.01)$. The FCR of LDL apo B was significantly increased by an average of $36 \pm 7 \%$ during $d l$-norgestrel treatment versus control $(0.33 \pm 0.01$ vs $0.25 \pm 0.02 \mathrm{pools} / \mathrm{d}, P<0.005)$. The enhancement of LDL apo B catabolism was not accompanied by any systematic change in pool size of LDL apo $B$ because LDL apo $B$ production rate increased reciprocally by an average of $36 \pm 13 \%$ during $d l$-norgestrel treatment versus control ( $12 \pm 1.4$ vs $9.4 \pm 1.7 \mathrm{mg} / \mathrm{kg}$ per d, $P<0.05$ ).

Evaluation of product-precursor relationships (37) between lipoprotein fractions indicated that VLDL were the sole precursors of IDL. As illustrated in a representative subject (Fig. 1), the decay curves of VLDL apo B consistently intersected those of IDL apo B at their peaks during both treatment and control periods. However, the LDL apo B specific activity curves consistently reached their peaks before they were intersected by their corresponding IDL curves. This is consistent with LDL entering the circulation directly (33) and/or via small, a rapidly turning over, hepatogenous pool(s) of VLDL apo B (38) which is not traceable with exogenous iodine labeling (25). The relative importance of the two pathways in the present experiments could not be determined. Comparisons of the areas under the specific activity curve as described by Goldberg et al. (33) indicated that LDL production derived from plasma VLDL and IDL could account for up to half of total $\mathrm{LDL}$ apo $\mathrm{B}$ production during treatment versus control ( $50 \mathrm{vs}$

Table IV. Kinetic Parameters of Human ${ }^{131}$ I-LDL Apo B Turnover in dl-Norgestrel-treated Postmenopausal Subjects

\begin{tabular}{|c|c|c|c|c|c|c|c|c|}
\hline \multirow[b]{2}{*}{ Subject } & \multirow[b]{2}{*}{ Period } & \multicolumn{2}{|c|}{ Half-life phase } & \multirow{2}{*}{$\begin{array}{l}\text { Fractional } \\
\text { catabolic } \\
\text { rate }\end{array}$} & \multirow[b]{2}{*}{ LDL apo B } & \multicolumn{2}{|c|}{ Production rate } & \multirow{2}{*}{$\begin{array}{l}\text { Fraction of } \\
\text { LDL apo B } \\
\text { production } \\
\text { derived from } \\
\text { IDL apo } B^{*}\end{array}$} \\
\hline & & I & II & & & Total & From IDL & \\
\hline & & \multicolumn{2}{|c|}{$h$} & pools/d & $m g / k g$ & \multicolumn{2}{|c|}{$m g / k g$ per $d$} & $\%$ \\
\hline \multirow[t]{2}{*}{1} & Control & 29 & 72 & 0.29 & 32 & 9.2 & 3.9 & 42 \\
\hline & Treated & 14 & 81 & 0.35 & 39 & 14 & 9.0 & 64 \\
\hline \multirow[t]{2}{*}{2} & Control & 45 & 150 & 0.22 & 33 & 7.3 & 4.0 & 55 \\
\hline & Treated & 18 & 85 & 0.33 & 25 & 8.2 & 4.5 & 55 \\
\hline \multirow[t]{2}{*}{3} & Control & 29 & 132 & 0.30 & 20 & 6.0 & 3.4 & 57 \\
\hline & Treated & 24 & 159 & 0.35 & 28 & 9.8 & 3.5 & 36 \\
\hline \multirow[t]{2}{*}{4} & Control & 45 & 156 & 0.22 & 39 & 8.4 & 4.2 & 50 \\
\hline & Treated & 20 & 88 & 0.31 & 41 & 13 & 6.6 & 51 \\
\hline \multirow[t]{2}{*}{5} & Control & 47 & 153 & 0.21 & 77 & 16 & 5.0 & 31 \\
\hline & Treated & 28 & 189 & 0.32 & 50 & 16 & 7.0 & 44 \\
\hline Mean & Control & 39 & 133 & 0.25 & 40 & 9.4 & 4.1 & 47 \\
\hline$\pm \mathrm{SE}$ & & 4 & 16 & 0.02 & 10 & 1.7 & 0.3 & 5 \\
\hline Mean & Treated & $21^{\ddagger}$ & 120 & $0.33^{\S}$ & 37 & $12^{\|}$ & $6.1^{\| 1}$ & 50 \\
\hline$\pm \mathrm{SE}$ & & 2 & 22 & 0.01 & 5 & 1.4 & 1.0 & 5 \\
\hline
\end{tabular}

${ }^{*}$ Calculated according to method of Goldberg et al. (33). ${ }^{\ddagger}$ Different from control, $P<0.01 .{ }^{\S}$ Different from control, $P<0.005$. $\quad$ Different from control, $P<0.05$. 


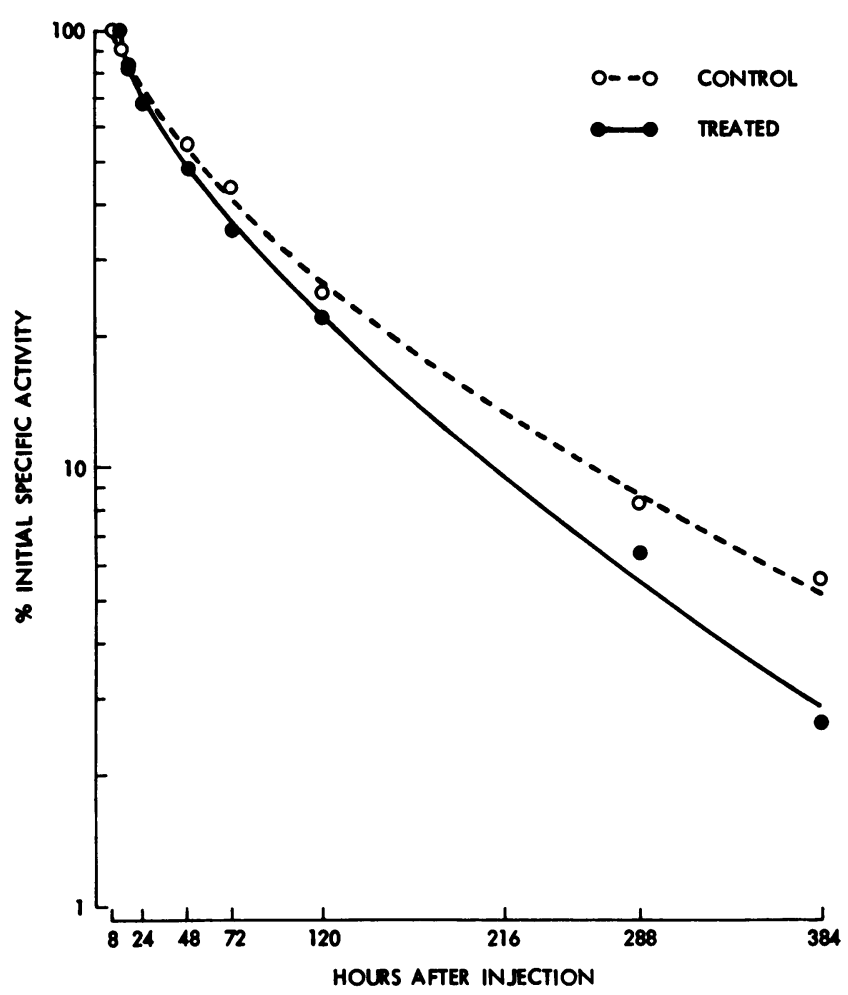

Figure 2. Specific radioactivity of LDL apo B expressed as percentage of the peak specific activity after intravenous injection of autologous ${ }^{131}$ I-labeled LDL for a representative subject.

$47 \%$, respectively). The consistent increase in production of LDL derived from VLDL via IDL accounted for most of the increase in total LDL apo B production during treatment versus control $(6.1 \pm 1.0 \mathrm{vs} 4.1 \pm 0.3 \mathrm{mg} / \mathrm{kg}$ per $\mathrm{d}, P<0.05$, Table IV).

\section{Discussion}

The present studies provide new insights into the mechanisms whereby a continuous low dosage of the progestin $d l$-norgestrel alone can modulate the concentrations of plasma lipoproteins in women with estrogen deficiency due to primary ovarian failure. Whereas low dosage $d l$-norgestrel $(0.075 \mathrm{mg} / \mathrm{d})$ combined with estradiol-17 $\beta(1 \mathrm{mg} / \mathrm{d})$ increase the FCR of VLDL, thereby lowering VLDL triglycerides (2), low dosage $d l$-norgestrel alone significantly reduces VLDL apo $B$ production rate and decreases mean VLDL apo B pool size (Table III). The reduction of plasma VLDL triglycerides during treatment with $d l$-norgestrel alone (Table II) is consistent with both reduced production of VLDL apo B and the previously demonstrated inhibition of triglyceride release from rat hepatocytes (9), likely involving, at least in part, inhibition of hepatic glycerol3-phosphate acyltransferase, a key enzyme of triglyceride synthesis (12). In contrast, similar low dosages of $d l$-norgestrel combined with estradiol-17 $\beta$ daily were found to lower VLDL triglycerides and VLDL apo B pool size by increasing FCR with unchanged production of VLDL apo B (3). Since VLDL were the sole precursors of IDL (see Results), the observed reduction in IDL cholesterol (Table II) and IDL apo B can be attributed, at least in part, to reduced rate of VLDL production during $d l$-norgestrel treatment. The consistent reduction of plasma total cholesterol (Table I, $P<0.06$ by sign test) is attributable to the combined reduction in VLDL-, IDL-, and
LDL-cholesterol ( Table II). Although low dosage $d l$-norgestrel had no detectable effect on HDL cholesterol during the 7-wk period of observation, combined administration of low doses of $d l$-norgestrel and estradiol-17 $\beta$ was found to significantly lower HDL cholesterol (2), as have sixfold higher norgestrel doses (39).

The present finding of increased plasma LDL apo B turnover with constant plasma concentration during administration of $d l$-norgestrel alone (Table IV) strongly contrasts with the reductions in LDL apo B production and concentration that were observed when a similar dose of $d l$-norgestrel was given together with estradiol-17 $\beta$ to postmenopausal women (3), but is consistent with enhanced production of LDL observed during progesterone treatment of female baboons (40). The low dosage $d l$-norgestrel given alone increased mean LDL catabolism to the same extent (i.e., $36 \%$ ) as $2 \mathrm{mg} / \mathrm{d}$ estradiol in another study of postmenopausal women (41). Whereas estradiol increased LDL apo B production by only $21 \%$ and lowered LDL apo B (41), $d l$-norgestrel increased LDL apo B production by $36 \%$ maintaining its concentration (Table IV). The known effects of estradiol on lipoprotein metabolism $(41,42)$ fail to explain the differences in metabolic effects observed between administration of $d l$-norgestrel alone versus $d l$-norgestrel combined with estradiol-17 $\beta(3)$ and the metabolic basis of the interaction of estradiol and $d l$-norgestrel in inhibiting $L D L$ apo B production (3) remains unclear. It is conceivable that $d l$-norgestrel given alone could bind to estrogen receptors (43) and/or other estrogen- or progesterone-responsive elements of other genes and induce estrogen-like effects on LDL metabolism. Other mechanisms of hormone action may also be possible. For instance, antiglucocorticoid effects have been attributed to progestin binding to glucocorticoid receptors (44). Levonorgestrel alone reduces plasma triglycerides in female rats in vivo and inhibits hepatocyte triglyceride synthesis in vitro, but not in the presence of estradiol (10). Nevertheless, plasma cholesterol is not reduced in the rat by either treatment.

The present finding of a slight, but consistent decrease in fasting plasma $\operatorname{Lp}(a)$ with administration of the present low dosage of $d l$-norgestrel could have implications for the reduction of coronary heart disease in postmenopausal women resulting from elevated plasma $\operatorname{Lp}(a)(16,17)$. The change in $\mathrm{Lp}$ (a) concentration is in the same direction, though the changes are smaller than with an 80-fold higher dose of stanozolol (45). Although $d l$-norgestrel shares HDL lowering effects with stanozolol, the actual mechanism underlying the reduction of $\operatorname{Lp}(\mathrm{a})$ by these agents is unknown.

The present findings with low dosage $d l$-norgestrel in women with ovarian failure provide new insights into progestin effects on lipoprotein metabolism and may have implications both for the design of progestin-only and combined estrogen/ progestin oral contraceptives for premenopausal women and the formulation of perhaps more widely acceptable continuous low dosage female hormonal replacement therapy in postmenopausal women (2), including those in whom moderate hypertriglyceridemia (46) may pose a risk of coronary heart disease and more severe hypertriglyceridemia may pose a risk of estrogen-induced pancreatitis $(47,48)$.

\section{Acknowledgments}

We thank Brian Sutherland and Sandra Kleinstiver for expert technical assistance. We thank Dale Hobbs for assistance with the dietary assessment and dietary protocols and Mary Cann for coordinating the stud- 
ies. We are grateful to Elene Wolfe for the graphic art and typing the manuscript.

This work was supported by grant MT 4248 from the Medical Research Council of Canada.

\section{References}

1. Goldzieher, J. W. 1989. Pharmacology of contraceptive steroids: a brief review. Am. J. Obstet. Gynecol. 160:1260-1264.

2. Plunkett, E. R., and B. M. Wolfe. 1992. Prolonged effects of a novel, low-dosage continuous progestin-cyclic estrogen replacement program in postmenopausal women. Am. J. Obstet. Gynecol. 166:117-121.

3. Wolfe, B. M., and M. W. Huff. 1989. Effects of combined estrogen and progestin administration on plasma lipoprotein metabolism in postmenopausal women. J. Clin. Invest. 83:40-45.

4. Nielsen, F. H., E. Honoré, K. Kristoffersen, N. J. Secher, and G. T. Pedersen. 1977. Changes in serum lipids during treatment with norgestrel oestradiolvalerate and cycloprogynon. Acta Obstet. Gynecol. Scand. 56:367-370.

5. Robertson, D. N., F. Alvarez, I. Sivin, V. Brache, J. Stern, P. Leon, and A. Faundes. 1981. Lipoprotein patterns in women in Santo Domingo using a levonorgestrel/estradiol contraceptive ring. Contraception. 24:469-480.

6. Foegh, M., F. Damgaard-Pederson, J. Gormsen, J. B. Knudsen, and G. Schou. 1980. Oral levo-norgestrel-testosterone effects on spermatogenesis, hormone levels, coagulation factors and lipoproteins in normal men. Contraception. 21:381-391.

7. Rössner, S., O. Frankman, and L. Marsk. 1979. Effects of various low dose contraceptive pills on serum lipoproteins. In Lipoprotein Metabolism. L. W. Hessel and H. H. J. Krans, editors. Elsevier Science Publishers B.V., Amsterdam. 91-98.

8. Silfverstolpe, G., A. Gustafson, G. Samsioe, and A. Svanborg. 1979. Lipid metabolic studies in oophorectomized women. Effects of three different progestogens. Acta Obstet. Gynecol. Scand. Suppl. 88:89-95.

9. Khokha, R., and B. M. Wolfe. 1984. Hypotriglyceridemic effects of levonorgestrel in rats. Atherosclerosis. 52:329-338.

10. Taves, E. H., and B. M. J. Wolfe. 1989. Estradiol is a potent inhibitor of the hypotriglyceridemic effect of levonorgestrel in female rats. Lipids. 24:669672.

11. Khokha, R., M. W. Huff, and B. M. Wolfe. 1986. Divergent effects of d-norgestrel on the metabolism of rat very low density and low density apolipoprotein B. J. Lipid Res. 27:699-705.

12. Khokha, R., P. A. Walton, F. Possmayer, and B. Wolfe. 1987. Effects of levonorgestrel on enzymes responsible for synthesis of triacylglycerols in rat liver. Biochim. Biophys. Acta. 918:120-125.

13. Henderson, B. E., A. Paganini-Hill, and R. K. Ross. 1991. Decreased mortality in users of estrogen replacement therapy. Arch. Intern. Med. 151:75-78.

14. Stampfer, M. J., G. A. Colditz, W. C. Willett, J. E. Manson, B. Rosner, F. E. Speizer, and C. H. Hennekens. 1991. Postmenopausal estrogen therapy and cardiovascular disease. N. Engl. J. Med. 325:756-762.

15. Williams, J. K., M. R. Adams, and H. S. Klopfenstein. 1990. Estrogen modulates responses of atherosclerotic coronary arteries. Circulation. 81:16801687.

16. Uterman, G. 1989. The mysteries of lipoprotein(a). Science (WAsh. DC). 246:904-910.

17. Meilahn, E. N., L. H. Kuller, K. A. Matthews, and E. A. Stein. 1991. $\mathrm{Lp}$ (a) concentrations among pre- and postmenopausal women over time: the healthy women study. Circulation. 84:II-546, No. 2170. (Abstr.)

18. Bengtsson, C., and O. Lindquist. 1978. Coronary heart disease during the menopause. In Coronary Heart Disease in Young Women. M. F. Oliver, editor. Churchill-Livingstone, Inc., New York. 234-242.

19. Blumenthal, S. 1979. Introduction. In Proceedings of the Conference on the Decline in Coronary Heart Disease Mortality. National Heart, Lung, and Blood Institute, National Institutes of Health, Bethesda, Maryland, October 2425, 1978. R. J. Havlik and M. Feinleib, editors. U. S. Department of Health, Education, and Welfare, NIH Publication No. 79-1610, May 1979. 3, 23, 32-33, 46, 236-243, 262, 287-290.

20. The Expert Panel. 1988. Report of the National Cholesterol Education Program Expert Panel on detection, evaluation and treatment of high blood cholesterol in adults. Arch. Intern. Ned. 148:36-69.

21. Reardon, M. F., N. H. Fidge, and P. J. Nestel. 1978. Catabolism of very low density lipoprotein B apoprotein in man. J. Clin. Invest. 61:850-860.

22. Huff, M. W., P. M. Giovannetti, and B. M. Wolfe. 1984. Turnover of very low-density lipoprotein-apoprotein B is increased by substitution of soybean protein for meat and dairy protein in the diets of hypercholesterolemic men. Am. J. Clin. Nutr. 39:888-897.
23. Huff, M. W., and D. E. Telford. 1985. Direct synthesis of low-density lipoprotein apoprotein B in the miniature pig. Metabolism. 34:36-42.

24. Havel, R. J., H. A. Eder, and J. H. Bragdon. 1955. The distribution and chemical composition of ultracentrifugally separated lipoproteins in human serum. J. Clin. Invest. 34:1345-1353.

25. Huff, M. W., D. E. Telford, K. Woodcroft, and W. L. P. Strong. 1985. Mevinolin and cholestyramine inhibit the direct synthesis of low density lipoprotein apolipoprotein B in miniature pigs. J. Lipid Res. 26:1175-1186.

26. Goodman, DeW. S., R. P. Noble, and R. B. Dell. 1973. Three-pool model of the long-term turnover of plasma cholesterol in man. J. Lipid Res. 14:178188.

27. Skinner, S. M., R. E. Clark, N. Baker, and R. A. Shipley. 1959. Complete solution of the three-compartment model in steady state after single injection of radioactive tracer. Am. J. Physiol. 196:238-244.

28. Goodman, DeW. S., and R. P. Noble. 1968. Turnover of plasma cholesterol in man. J. Clin. Invest. 47:231-241.

29. Gurpide, E., J. Mann, and E. Sandberg. 1964. Determination of kinetic parameters in a two-pool system by administration of one or more tracers. Biochemistry. 3:1250-1255.

30. Nestel, P. J., M. F. Reardon, and N. H. Fidge. 1979. Very low density lipoprotein B-apoprotein kinetics in human subjects. Relationships between pool size, flux, and removal rate. Circ. Res. 45:35-41.

31. Huff, M. W., W. C. Breckenridge, W. L. P. Strong, and B. M. Wolfe. 1988. Metabolism of apolipoproteins C-II, C-III, and B in hypertriglyceridemic men. Changes after heparin-induced lipolysis. Arteriosclerosis. 8:471-479.

32. Wolfe, B. M., and S. P. Ahuja. 1977. Effects of intravenously administered fructose and glucose on splanchnic metabolism of plasma triglycerides in hypertriglyceridemic men. Metab. Clin. Exp. 26:963-978.

33. Goldberg, I. J., N.-A. Le, H. N. Ginsberg, J. Paterniti, Jr., and W. V. Brown. 1983. Metabolism of apoprotein B in cynomolgus monkey: evidence for independent production of low-density lipoprotein apoprotein B. Am. J. Physiol. 244:E196-E201.

34. Warnick, G. R., and J. J. Albers. 1978. A comprehensive evaluation of the heparin-manganese precipitation procedure for estimating high density lipoprotein cholesterol. J. Lipid Res. 19:65-76.

35. Snedecor, G. W., and W. G. Cochran. 1967. The comparison of two samples. In Statistical Methods. 6th edition. Iowa State University Press, Ames, IA. 91-119.

36. Zar, J. H. 1974. Biostatistical Analysis. Prentice-Hall, Inc., Englewood Cliffs, NJ. 290-291.

37. Zilversmit, D. B. 1960. The design and analysis of isotope experiments. Am. J. Med. 29:832-848.

38. Shames, D. M., and R. J. Havel. 1991. De novo production of low density lipoproteins: fact or fancy. J. Lipid Res. 32:1099-1112.

39. Tikkanen, M. J., E. A. Nikkilä, T. Kuusi, and S. Sipinen. 1981. Differential effects of two progestins on plasma high density lipoprotein $\left(\mathrm{HDL}_{2}\right)$ and postheparin plasma hepatic lipase activity. Atherosclerosis. 40:365-369.

40. Kushwaha, R. S., D. M. Foster, P. H. R. Barrett, and K. D. Carey. 1990. Effect of estrogen and progesterone on metabolism of apoprotein B in baboons. Am. J. Physiol. 258:E172-E183.

41. Walsh, B. W., I. Schiff, B. Rosner, L. Greenberg, V. Ravnikar, and F. M. Sacks. 1991. Effects of postmenopausal estrogen replacement on the concentrations and metabolism of plasma lipoproteins. N. Engl. J. Med. 325:1196-1204.

42. Eriksson, M., L. Berglund, M. Rudling, P. Henriksson, and B. Angelin. 1989. Effects of estrogen on low density lipoprotein metabolism in males. Shortterm and long-term studies during hormonal treatment of prostatic carcinoma. $J$. Clin. Invest. 84:802-810.

43. Pavlik, E. J., and P. B. Coulson. 1976. Modulation of estrogen receptors in four different target tissues: differential effects of estrogen vs progesterone. $J$. Steroid Biochem. 7:369-376.

44. Xu, X., J. Hoebeke, and P. Björntorp. 1990. Progestin binds to the glucocorticoid receptor and mediates antiglucocorticoid effect in rat adipose precursor cells. J. Steroid Biochem. 36:465-471.

45. Albers, J. J., H. McA. Taggart, D. Applebaum-Bowden, S. Haffner, C. H Chestnut III, and W. R. Hazzard. 1984. Reduction of lecithin-cholesterol acyltransferase, apolipoprotein $\mathrm{D}$ and the $\mathrm{Lp}(\mathrm{a})$ lipoprotein with the anabolic steroid stanozolol. Biochim. Biophys. Acta. 795:293-296.

46. Johansson, S., G. Bondjers, G. Fager, H. Wedel, A. Tsipogianni, S.-O Olafsson, A. Vedin, O. Wiklund, and C. Wilhelmsson. 1988. Serum lipids and apolipoprotein levels in women with acute myocardial infarction. Arteriosclerosis. 8:742-749.

47. Glueck, C. J., D. Scheel, J. Fishback, and P. Steiner. 1972. Estrogen-induced pancreatitis in patients with previously covert familial type $\mathrm{V}$ hyperlipoproteinemia. Metab. Clin. Exp. 21:657-666.

48. Bank, S., and I. N. Marks. 1970. Hyperlipaemic pancreatitis and the pill. Postgrad. Med. J. 46:576-588. 